Original Paper http://ajol.info/index.php/ijbcs http://indexmedicus.afro.who.int

\title{
In vitro study for antifungal compounds from Parinari curatellifolia (Chrysobalanaceae) and Terminalia sericea (Combretaceae)
}

\author{
Mourice Victor Nyangabo MBUNDE ${ }^{*}$, Ester INNOCENT ${ }^{2}$, Faith $\mathrm{MABIKI}^{3}$ and \\ Pher G. ANDERSSON ${ }^{4}$
}

\author{
${ }^{1}$ Department of Natural Products Development and Formulation, Institute of Traditional Medicine, Muhimbili \\ University of Health and Allied Sciences, P.O. Box 65001, Dar es salaam, Tanzania. \\ ${ }^{2}$ Department of Biological and Pre-clinical Studies, Institute of Traditional Medicine, Muhimbili University of \\ Health and Allied Sciences, P.O. Box 65001, Dar es salaam, Tanzania. \\ ${ }^{3}$ Department of Chemistry and Physics, Solomon Mahlangu College of Science and Education, Sokoine \\ University of Agriculture, P.O. Box 3038, Morogoro, Tanzania. \\ ${ }^{4}$ Department of Organic Chemistry, Stockholm University, The Arrhenius Laboratory, P.O. Box 10691, \\ Stockholm, Sweden. \\ ${ }^{*}$ Corresponding author; E-mail: mmbunde@muhas.ac.tz, Mobile: +255 784864417
}

\section{ACKNOWLEDGMENTS}

This work was funded by Swedish Research Council (SRC).

\begin{tabular}{lll}
\hline Received: 06-07-2020 & Accepted: 03-09-2020 & Published: 28-02-2021 \\
\hline
\end{tabular}

\begin{abstract}
Parinari curatellifolia (Chrysobalanaceae) and Terminalia sericea (Combretaceae) have been traditionally used in Southern Highlands of Tanzania for treatment of various infectious disorders. The present study aimed to evaluate antifungal activity of the isolated compounds from Parinari curatellifolia and Terminalia sericea plant species. The ethyl acetate extract of the root barks from Parinari curatellifolia and Terminalia sericea were fractionated using column chromatography. The structures of compounds were established using both 1D and 2D-NMR spectroscopic techniques while antifungal activities of the fractions and isolated compounds were evaluated using broth microdilution assay against Candida albicans, Cryptococcus neoformans and Aspergillus niger species. Two known compounds toddalolactone (1) and 10-hydroxy-13-methoxy-9methyl-15-oxo-20-norkaur-16-en-18-oic acid t-lactone (2) from P. curatellifolia and two compounds Sericic acid (3) and sericoside (4) from $T$. sericea were isolated and their structures identified and confirmed by spectral data obtained and from the literatures. Strong antifungal activity was shown by Sericic acid (3) with MIC value of $0.07 \mathrm{mg} / \mathrm{ml}$ against $C$. albicans and C. neoformans. Isolation of toddalolactone (1) from Parinari curatellifolia as well as the antifungal activity of Sericic acid (3) from Terminalia sericea is being reported for the first time. Bioactivity of these compounds support traditional use of the studied plants.
\end{abstract}

(C) 2021 International Formulae Group. All rights reserved.

Keywords: Sericic acid, toddalolactone, fungi, antifungal, Parinari curatellifolia, Terminalia sericea. 


\section{INTRODUCTION}

Plants have been used traditionally over decades in the treatment of fungal infections or related ailments in most parts of world including Tanzania. Medicinal herbs constitute an indispensable component of traditional medicine practiced worldwide due to the low cost, perceived safety, bio-degradability, easy access and ancestral experiences (Ogunnusi et al., 2010). A number of plants used in traditional medicines are currently being investigated for treatment of fungal infections which are common opportunistic infections among people with immunocompromised conditions like HIV/IADS and cancer patients (Diesse et al., 2017; Fokou et al., 2017). Some of the already identified plants are used as mouth preparations (Fyhrquist et al., 2002) and others are made in the form of ointments or creams for topical use on the skin (Chhetri et al., 2010). Ethnobotanical study undertaken in Iringa and Njombe regions has revealed that, the plant species namely Terminalia sericea Burch. Ex. DC (Combretaceae) locally known as "Mpululu" and Parinari curatellifolia (Chrysobalanaceae) locally called "Msaula" among the Hehe tribe of Iringa, Tanzania, are used for the treatment of anaemia, diabetes, diarrhea, gonorrhea and vaginal douches (Mbunde et al., 2016). Previously, T. sericea aqueous and methanol extracts of $T$. sericea was reported to have no antibacterial activity against Bacillus subtilis, Staphylococcus aureus and Staphylococcus epidermidis, but more recent studies have reported the presence of antibacterial activity in the leaves, roots and stem barks (Fyhrquist et al., 2002). Also, antifungal activity against Candida albicans was reported in the methanolic extract of $T$. sericea (Masoko et al., 2005). Reports on biological assays against various pathogenic organisms revealed that, Parinari capensis contains antimalarial (Uys et al., 2002), antifungal, antibacterial (Chukwudi et al., 2014; Angaman et al., 2018), and antioxidant (Nhukarume et al., 2009) while ethyl acetate root extract of Parinari curatellifolia exhibited anticancer activity (Lee et al., 1996).
Based on the wide use of these plants in Southern Tanzania, the present study was carried out to isolate pure compounds from Parinari curatellifolia and Terminalia sericea plants and evaluate the antifungal effect against selected pathogenic fungi like moulds and yeast.

\section{MATERIALS AND METHODS Reagents}

Methanol, Ethanol (absolute), Dichloromethane, Ethyl acetate, Petroleum ether were purchased from Fluka Chemie $\mathrm{GmbH} \quad$ (Sigma-Aldrich®, Zwijndrecht, Netherlands), Dimethyl sulfoxide (DMSO) was from Sigma ${ }^{\circledR}$ (Poole, Dorset, UK), TLC silica gel pre-coated plates (Merck-Germany), Silica gel-60 for column (0.063-0.200 mm; 70230 mesh) (Merck-Germany). Sabour dextrose agar and broth from HIMEDIA ${ }^{\circledR}$ (Himedia Laboratories Pvt Ltd, Mumbai, INDIA), $p$ Iodonitrotetrazolium chloride was bought from SIGMA ${ }^{\circledR}$ (Sigma- Aldrich ${ }^{\circledR}$, St Louis, USA), Microtitre plates (Clear Flat Bottom Polystyrene, TC-Treated, Individually Wrapped, Sterile, $1 \times 8$ Stripwell ${ }^{\mathrm{TM}}$ ) was from Sigma ${ }^{\circledR}$ were supplied by TechnoNet solutions, Tanzania.

\section{Collection of plant materials}

The roots of Terminalia sericea and Parinari curatellifolia were collected from Mafinga, Iringa in Southern Tanzania in June 2015. Identification and preparation of the voucher specimens was done with the aid of a Botanist from University of Dar es Salaam and voucher specimens (number MNM15 for $T$. sericea and voucher specimen number MNM10 for $P$. curatellifolia) kept at the Herbarium of the Institute of Traditional Medicine, Muhimbili University of Health and Allied Sciences.

\section{Extraction and isolation of pure compounds}

The root barks of Parinari curatellifolia and Terminalia sericea were air-dried, cut into small pieces, ground using a machine grinder and subsequently soaked at room temperature 
for 48 hours using ethyl acetate then followed by ethanol respectively. The crude extracts were filtered and concentrated in vacuo using a rotary evaporator with the bath temperature maintained at $40{ }^{\circ} \mathrm{C}$.

Ethyl acetate extract of $P$. curatellifolia root bark (30 g) was packed to column chromatography on silica gel $(100 \mathrm{~g})$ initially eluting with $100 \%$ petroleum ether adding ethyl acetate to get several fractions which were then combined based on similarity in the TLC to give 16 fractions. Repeated column chromatograph of fraction $\mathbf{3}$ on silica gel eluted with $1: 1 \% \quad \mathrm{v} / \mathrm{v}$ Ethyl acetate and Dichloromethane obtained three sub-fractions which were $3 \mathrm{~A}, 3 \mathrm{~B}$ and $3 \mathrm{C}$. Sub fraction 3B was then purified by preparative TLC to yield Toddalolactone (1) $(14 \mathrm{mg})$. Fraction 4 was purified by crystallization in methanol to yield 10-hydroxy-13-methoxy-9-methyl-15-oxo-20norkaur-16-en-18-oic acid t-lactone (2) (20 $\mathrm{mg})$.

The ethanol extract of root bark of Terminalia sericea was sequentially fractionated by vacuum liquid chromatography (VLC) using petroleum ether, dichloromethane, ethyl acetate and methanol. The ethyl acetate fraction $(20 \mathrm{~g})$ was packed in a column in silica gel eluting in gradient with solvents of different polarities such as petroleum ether, dichloromethane and ethyl acetate. Several fractions were collected and combined to get $9^{\text {th }}$ fractions. The $8^{\text {th }}$ fraction was dissolved in ethyl acetate and formed two layers thus decanted to separate soluble and insoluble fraction. Insoluble fraction was crystallized with methanol to yield the compound named Sericic acid (3). Sericoside (4) $(90 \mathrm{mg})$ was obtained as pure compounds after eluting methanol fraction with ethyl acetate then chromatographed in sephadex LH20 to get fractions in which three fractions were subjected to crystallization using methanol to yield the compound.

\section{Spectroscopic analysis}

Spectroscopic analysis of the isolated compounds from $P$. curatellifolia was done at Stockholm University, Sweden while compounds from $T$. sericea were analysed at Dortmund University, Germany. Both 1D's and 2D's NMR analyses (1H, 13C-NMR, COSY, HSQC, HCCOSW, DEPT and HMBC spectra) were recorded on a Bruker Avance DRX-600 (600 MHz) NMR spectrometer. NMR data were processed using Mestre Nova Software (Mestre lab Research S.L.) and Topspin software (Bruker BioSpin Corporation).

\section{Test for antifungal activity}

\section{Preparation of microorganisms}

Pure cultures of human pathogenic fungi: Candida albicans (ATCC 90028), Cryptococcus neoformans (ATCC 90112), Aspergillus niger (AZN 8240) and Candida albicans clinical isolates, were obtained from the Department of Microbiology and Immunology, Muhimbili University of Health and Allied Sciences (MUHAS). The fungal species were maintained on sabouraud dextrose agar at $4{ }^{\circ} \mathrm{C}$. The fungal species were inoculated in sabouraud dextrose broth (SDB) and Muller Hinton broth and incubated at $35^{\circ} \mathrm{C}$ prior to screening tests. Clotrimazole was prepared from solution of distilled water and used as positive controls.

\section{Determination of Minimum Inhibitory Concentration (MIC) by broth micro dilution method}

The MIC for the crude extracts and isolated compounds was determined by broth microdilution tests performed in a sterile flat bottom 96- well polystyrene microtiter plates. The extracts and isolated compounds were tested against standard and clinical isolates of fungi like Candida albicans, Cryptococcus neoformans and Aspergillus niger. Microorganism's inocula were prepared from 24 hours grown cultures. Serial two-fold dilution method was performed as follows; 100 $\mu l$ of broth (Sabouraud's dextrose broth) were pipetted into each well. To each well of the first row $100 \mu 1$ of the compound solution or fluconazole or solvent was added. Each of the test materials were tested in duplicate. After thorough mixing, $100 \mu \mathrm{l}$ of the mixture was drawn and transferred to the second well in the 
row and after mixing well again $100 \mu$ of the mixture was drawn and transferred to the third well in the row. This procedure was repeated until the last well in the row. Then $100 \mu 1$ of the mixture was discarded from each last well of the row. One additional row was used as growth control, in which no drug was added; instead a blank culture medium was added. The inoculated microtiter plates were incubated at $37^{\circ} \mathrm{C}$ for 24 hours for moulds and 48 hours for yeast like fungus. MIC values were detected using tetrazonium salt indicator, (Iodonitrotetrazolium chloride) which changes colour from pink (for presence of growth) to colourless (for no growth). Before recording of experimental results in the MIC assay plate, a volume of $40 \mu \mathrm{l}$ of a $0.2 \%$ INT was pipetted into each well and incubated at $37{ }^{\circ} \mathrm{C}$ for 2 hours. The lowest concentration at which no growth observed indicated by colourless colour and this was taken as MIC value.

\section{RESULTS}

\section{Isolation and characterization of compounds}

Toddalolactone (1) was observed to be white crystals, UV/VIS on positive TLC and purple in colour when the TLC is sprayed with vanillin Sulphuric acid mixture. It was soluble in Dichloromethane and Ethyl acetate, insoluble in Methanol. Rf value 0.57 (100\% DCM). Reported Molecular Weight, $\mathrm{C}_{16} \mathrm{H}_{20} \mathrm{O}_{6}$, $308.33 \mathrm{~g} / \mathrm{mol}$ ( $\mathrm{Yu}$ et al., 2017). ${ }^{1} \mathrm{H}$ and ${ }^{13} \mathrm{C}$ NMR data are presented in Table 1.

10-hydroxy-13-methoxy-9- methyl-15oxo-20-norkaur-16-en-18-oic acid 1-lactone (2) was observed to be white with needle-like crystals structures, UV positive in TLC and purple in colour when the TLC is prayed with vanillin Sulphuric acid mixture. It was soluble in Dichloromethane and Ethyl acetate, insoluble in Methanol. They were white needle crystals with $\mathrm{Rf}$ value 0.45 (100\%DCM). Reported Molecular Weight $344.0 \mathrm{~g} / \mathrm{mol}$, $\mathrm{C}_{21} \mathrm{H}_{28} \mathrm{O}_{4}$ (Garo et al., 1997). ${ }^{1} \mathrm{H}$ and ${ }^{13} \mathrm{C}$ NMR data are presented in Table 2 .

Sericic acid, $(2 \alpha, 3 \beta, 19 \alpha, 24 \quad-$ tetrahydroxy-olean-12-en-28-oic acid) (3) white amorphous, soluble in Dichloromethane and Ethyl acetate. Reported Molecular Weight 504. $345 \mathrm{~g} / \mathrm{mol}, \mathrm{C}_{30} \mathrm{H}_{48} \mathrm{O}_{6}$ (Hess and Monache, 1999). ${ }^{1} \mathrm{H}$ and ${ }^{13} \mathrm{C}$ NMR data are presented in Table 3.

Glucosyl - $2 \alpha, 3 \beta, 19 \alpha, 24 \quad-$ tetrahydroxy-olean - 12 - en - 28-oate (Sericoside) (4) was white in colour, soluble in Ethyl acetate. Molecular Weight $666.8 \mathrm{~g} / \mathrm{mol}$, $\mathrm{C}_{36} \mathrm{H}_{58} 0_{11}$ (Terreaux et al., 1996). ${ }^{1} \mathrm{H}$ and ${ }^{13} \mathrm{C}$ NMR data are shown in Table 4.

\section{Antifungal activity of isolated compounds Minimal Inhibitory Concentration values of the different crude extracts and isolated compounds against the pathogenic yeasts and moulds were determined and reported in Table 5. According to Gibbons (2004), antimicrobial activity is classified into the following categories: $M I C<1 \mathrm{mg} / \mathrm{ml}$ : Good antimicrobial activity, $M I C>1 \mathrm{mg} / \mathrm{ml}$ or $<4$ $\mathrm{mg} / \mathrm{ml}$ : Moderate good antimicrobial activity, MIC $=4 \mathrm{mg} / \mathrm{ml}$ or $<6 \mathrm{mg} / \mathrm{ml}:$ Moderate antimicrobial activity, MIC > $6 \mathrm{mg} / \mathrm{ml}$ : Poor antimicrobial activity.}

Table 1: A table showing NMR $\left(\mathrm{CDCl}_{3}, 600 \mathrm{MHz}\right)$ data for Toddalolactone (1) from Parinari curatellifolia

\begin{tabular}{llll}
\hline Position & ${ }^{13} \mathbf{C ~ N M R ~ C D C l}_{3}$ & ${ }^{\mathbf{1}} \mathrm{H} \mathrm{NMR} \mathrm{CDCl}_{3}$ & $\begin{array}{l}\text { Literature } \\
\text { al., 2017) }\end{array}$ \\
\hline 2 & 161.6 & & 160.9 \\
3 & 112.9 & $6.26(1 \mathrm{H}, \mathrm{d}, J=12.0 \mathrm{~Hz})$ & 112.8 \\
4 & 138.9 & $7.85(1 \mathrm{H}, \mathrm{d}, J=12.0 \mathrm{~Hz})$ & 138.7 \\
$4 \mathrm{a}$ & 107.4 & & 107.3 \\
5 & 156.1 & $3.88(6 \mathrm{H}, \mathrm{d}, J=6.0 \mathrm{~Hz})$ & 156.0 \\
6 & 118.0 & & 117.9
\end{tabular}




$\begin{array}{llll}7 & 161.1 & & 161.5 \\ 8 & 95.9 & 6.65(1 \mathrm{H}, \mathrm{s},) & 95.8 \\ 8 \mathrm{a} & 155.2 & 2.95(1 \mathrm{H}, \mathrm{dd}, J=6,12 \mathrm{~Hz}) & 155.1 \\ 1^{\prime \prime} & 26.3 & 3.59(1 \mathrm{H}, \mathrm{d}, J=12, \mathrm{~Hz},) & 78.1 \\ 2^{\prime \prime} & 78.2 & & 72.9 \\ 3^{\prime \prime} & 73.0 & 1.30(6 \mathrm{H}, \mathrm{d}, J=6.0 \mathrm{~Hz}) & 23.7 \\ 4^{\prime \prime} & 23.8 & 2.75(1 \mathrm{H}, \mathrm{m}) & 26.2 \\ 5^{\prime \prime} & 26.25 & & 63.2 \\ \text { OMe-C } & 63.4 & & 56.3 \\ \text { OMe-C } & 56.4 & & \end{array}$

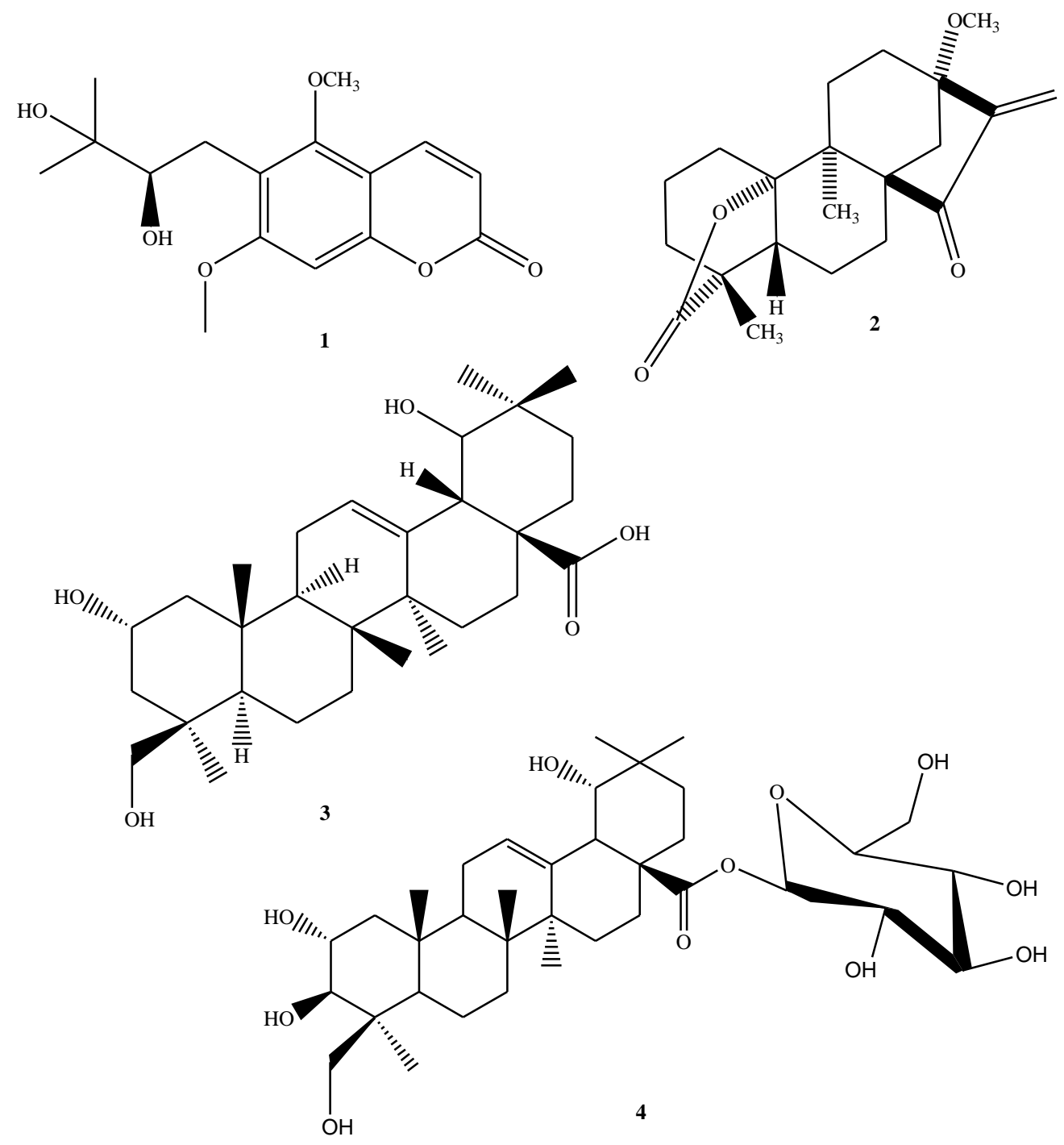

Figure 1: Structures of the isolated compounds toddalolactone (1) and 10-hydroxy-13-methoxy-9methyl-15-oxo-20-norkaur-16-en-18-oic acid t-lactone (2),Sericic acid (3) and sericoside (4). 
Table 2: A table showing NMR (600 MHz) data for 10-hydroxy-13-methoxy-9- methyl-15-oxo-20norkaur-16-en-18-oic acid t-lactone (2) from Parinari curatellifolia.

\begin{tabular}{llll}
\hline Position & ${ }^{13} \mathbf{C ~ N M R ~ C D C l}_{3}$ & ${ }^{1} \mathbf{H ~ N M R ~ C D C l}_{3}$ & $\begin{array}{l}\text { Literature } \mathbf{C D C l}_{3} \text {, (Garo et } \\
\text { al., 1997) }\end{array}$ \\
\hline 1 & 31.3 & $1.16(2 \mathrm{H}, \mathrm{m})$ & 31.0 \\
2 & 20.2 & $2 \mathrm{H}(1.60, \mathrm{~m})$ & 19.9 \\
3 & 35.4 & $1.72(2 \mathrm{H}, \mathrm{m})$ & 35.1 \\
4 & 47.6 & & 47.3 \\
5 & 52.0 & $2.52(\mathrm{IH}, \mathrm{dd}, \mathrm{J}=6.0,12.0 \mathrm{~Hz})$ & 51.7 \\
6 & 18.3 & $1.27(3 \mathrm{H}, \mathrm{s})$ & 18.0 \\
7 & 25.6 & $1.50(2 \mathrm{H}, \mathrm{m})$ & 25.3 \\
8 & 54.5 & & 54.2 \\
9 & 43.2 & & 42.9 \\
10 & 87.5 & & 87.2 \\
11 & 31.8 & $1.87(2 \mathrm{H}, \mathrm{m})$ & 31.5 \\
12 & 34.9 & $2.17(2 \mathrm{H}, \mathrm{m})$ & 34.5 \\
13 & 79.9 & & 79.6 \\
14 & 40.7 & $2.17(2 \mathrm{H}, \mathrm{m})$ & 40.4 \\
15 & 208.3 & & 208.0 \\
16 & 147.6 & & 147.3 \\
17 & 116.7 & $5.36(1 \mathrm{H}, \mathrm{s})$ & 116.4 \\
18 & 180.6 & & 180.3 \\
19 & 17.2 & $1.10(3 \mathrm{H}, \mathrm{s})$ & 16.9 \\
20 & 18.7 & $1.72(2 \mathrm{H}, \mathrm{m})$ & 18.4 \\
21 & 50.3 & $3.25(3 \mathrm{H}, \mathrm{s})$ & 50.0 \\
\hline
\end{tabular}

Table 3: A table showing NMR $\left(\mathrm{CD}_{3} \mathrm{OD}, 600 \mathrm{MHz}\right)$ data for Sericic acid (3) from Terminalia sericea

\begin{tabular}{llll}
\hline Position & ${ }^{13} \mathbf{C}$ NMR CD $\mathbf{~}_{3}$ OD & ${ }^{1} \mathbf{H ~ N M R ~ C D}_{\mathbf{3}} \mathbf{O D}$ & $\begin{array}{l}\text { Literature Pyridine-d5 } \\
\text { (Hess \& Monache, 1999) }\end{array}$ \\
\hline 1 & & & 47.4 \\
2 & 44.8 & $3.70(1 \mathrm{H}, \mathrm{m})$ & 68.6 \\
3 & 67.7 & $2.96(2 \mathrm{H}, \mathrm{m})$ & 85.7 \\
4 & 84.1 & & 43.9 \\
5 & 43.2 & $0.90(1 \mathrm{H}, \mathrm{s})$ & 56.5 \\
6 & 55.4 & $1.36(2 \mathrm{H}, \mathrm{m})$ & 19.3 \\
7 & 18.1 & $1.22(1 \mathrm{H}, \mathrm{m})$ & 33.6 \\
8 & 32.3 & & 40.0 \\
9 & 40.7 & $1.70(3 \mathrm{H}, \mathrm{m})$ & 48.4 \\
10 & 47.6 & & 38.4 \\
11 & 38.9 & $0.88(2 \mathrm{H}, \mathrm{s})$ & 28.8
\end{tabular}


M. V. N. MBUNDE et al. /Int. J. Biol. Chem. Sci. 15(1): 367-378, 2021

\begin{tabular}{llll}
12 & 122.7 & $5.23(1 \mathrm{H}, \mathrm{t}, J=3.42 \mathrm{~Hz})$ & 123.6 \\
13 & 142.8 & & 144.9 \\
14 & 37.4 & $1.53(2 \mathrm{H}, \mathrm{m})$ & 42.1 \\
15 & 32.1 & $1.90(2 \mathrm{H}, \mathrm{m})$ & 29.1 \\
16 & 23.3 & $1.83(1 \mathrm{H}, \mathrm{dd}, J=4.44,14.1 \mathrm{~Hz})$ & 24.4 \\
17 & 45.8 & $2.96(2 \mathrm{H}, \mathrm{t}, J=3.78 \mathrm{~Hz})$ & 46.0 \\
18 & 42.5 & $3.16(1 \mathrm{H}, \mathrm{d}, J=3.72 \mathrm{~Hz})$ & 81.2 \\
19 & 80.5 & & 35.7 \\
20 & 34.2 & $1.69(3 \mathrm{H}, \mathrm{m})$ & 28.3 \\
21 & 27.5 & $2.20(1 \mathrm{H}, \mathrm{hex}, J=12.6 \mathrm{~Hz})$ & 29.9 \\
22 & 27.6 & $1.21(3 \mathrm{H}, \mathrm{s})$ & 24.1 \\
23 & 23.2 & $3.30(1 \mathrm{H}, \mathrm{d}, J=11.22)$ & 65.6 \\
24 & 64.3 & $0.87(3 \mathrm{H}, \mathrm{s})$ & 17.3 \\
25 & 15.8 & $0.66(3 \mathrm{H}, \mathrm{s})$ & 17.1 \\
26 & 15.5 & $1.15(3 \mathrm{H}, \mathrm{s})$ & $24.7=$ \\
27 & 21.9 & & 180.9 \\
28 & 180.5 & $0.84(3 \mathrm{H}, \mathrm{s})$ & 29.1 \\
29 & 26.8 & $1.92(2 \mathrm{H}, \mathrm{m})$ & 24.7 \\
30 & 23.19 & & \\
\hline
\end{tabular}

Table 4: A table showing NMR $\left(\mathrm{CD}_{3} \mathrm{OD}, 600 \mathrm{MHz}\right)$ data for Sericoside (4) from Terminalia sericea

\begin{tabular}{|c|c|c|c|}
\hline Position & ${ }^{13} \mathrm{C} \mathrm{NMR} \mathrm{CD} \mathrm{CD}_{3} \mathrm{OD}$ & ${ }^{1} \mathrm{H}$ NMR CD $\mathrm{CD}_{3} \mathrm{OD}$ & $\begin{array}{l}\text { Literature } \mathrm{CDCl}_{3} \text { (Terreaux } \\
\text { et al., 1996) }\end{array}$ \\
\hline 1 & 47.9 & $0.80(2 \mathrm{H}, \mathrm{t}, J=11.9 \mathrm{~Hz})$ & 47.5 \\
\hline 2 & 69.7 & $3.69(2 \mathrm{H}, \mathrm{m})$ & 68.6 \\
\hline 3 & 86.1 & $2.95(1 \mathrm{H}, \mathrm{d}, J=9.544 \mathrm{~Hz})$ & 85.7 \\
\hline 4 & 44.5 & & 43.9 \\
\hline 5 & 57.4 & $0.88(3 \mathrm{H}, \mathrm{m})$ & 56.6 \\
\hline 6 & 20.1 & $1.34(2 \mathrm{H}, \mathrm{m})$ & 19.5 \\
\hline 7 & 34.2 & $1.23(2 \mathrm{H}, \mathrm{m})$ & 33.5 \\
\hline 8 & 41.0 & & 40.2 \\
\hline 9 & 49.5 & $1.68(\mathrm{IH}, \mathrm{m})$ & 48.5 \\
\hline 10 & 39.4 & & 38.4 \\
\hline 11 & 25.2 & $1.88(2 \mathrm{H}, \mathrm{dt}, J=4.9, \mathrm{~J}=, 8.7)$ & 24.5 \\
\hline 12 & 124.8 & $5.23(1 \mathrm{H}, \mathrm{t}, J=6.96)$ & 123.8 \\
\hline 13 & 144.6 & & 144.3 \\
\hline 14 & 42.7 & & 42.0 \\
\hline 15 & 29.6 & $1.69(2 \mathrm{H}, \mathrm{m})$ & 28.9 \\
\hline 16 & 28.5 & $2.23(\mathrm{IH}$, sept $)$ & 27.9 \\
\hline 17 & 47.2 & & 46.4 \\
\hline
\end{tabular}


M. V. N. MBUNDE et al. /Int. J. Biol. Chem. Sci. 15(1): 367-378, 2021

\begin{tabular}{llll}
18 & 45.2 & $2.95(2 \mathrm{H}, \mathrm{d}, J=9.54 \mathrm{~Hz})$ & 44.6 \\
19 & 82.5 & $3.17(1 \mathrm{H}, \mathrm{d}, J=3.78 \mathrm{~Hz})$ & 80.9 \\
20 & 36.1 & & 35.5 \\
21 & 29.5 & $0.91(2 \mathrm{H}, \mathrm{m})$ & 29.0 \\
22 & 33.4 & $1.56(2 \mathrm{H}, \mathrm{m})$ & 33.0 \\
23 & 25.1 & $1.19(3 \mathrm{H}, \mathrm{s})$ & 24.6 \\
24 & 66.3 & $3.93(1 \mathrm{H}, \mathrm{d}, J=11.2 \mathrm{~Hz})$ & 65.6 \\
25 & 17.6 & $0.85(3 \mathrm{H}, \mathrm{d}, J=6.36 \mathrm{~Hz})$ & 17.2 \\
26 & 17.8 & $0.63(3 \mathrm{H}, \mathrm{s})$ & 17.5 \\
27 & 23.9 & & 24.1 \\
28 & 178.7 & & 177.2 \\
29 & 28.8 & $0.85(3 \mathrm{H}, \mathrm{d}, J=6.36 \mathrm{~Hz})$ & 28.7 \\
30 & 25.3 & $0.85(3 \mathrm{H}, \mathrm{t}, J=9.2)$ & 24.8 \\
Glucose & & & \\
1 & 95.9 & $5.27(1 \mathrm{H}, \mathrm{d}, J=8.16 \mathrm{~Hz})$ & 95.8 \\
$2^{\prime}$ & 74.1 & $3.22(2 \mathrm{H}, \mathrm{m})$ & 74.1 \\
$3^{\prime}$ & 78.9 & $3.29(2 \mathrm{H}, \mathrm{m})$ & 79.3 \\
4, & 71.2 & $3.26(2 \mathrm{H}, \mathrm{d}, J=7.08 \mathrm{~Hz})$ & 71.0 \\
$5^{\prime}$ & 78.5 & $3.29(2 \mathrm{H}, \mathrm{m})$ & 78.9 \\
6 & 62.5 & $3.72(2 \mathrm{H}, \mathrm{m})$ & 62.1 \\
\hline
\end{tabular}

Table 5: MIC results $(\mathrm{mg} / \mathrm{ml})$ for crude extract and compounds isolated from Parinari curatellifolia and Terminalia sericea

\begin{tabular}{lcccc}
\hline $\begin{array}{c}\text { Fraction/ compound } \\
(\mathbf{m g} / \mathbf{m l})\end{array}$ & $\begin{array}{c}\text { C. albicans ATCC } \\
\mathbf{9 0 0 2 8}\end{array}$ & $\begin{array}{c}\text { C. albicans } \\
\text { clinical }\end{array}$ & $\begin{array}{c}\text { C. neoformans } \\
\text { ATCC 90112 }\end{array}$ & $\begin{array}{c}\text { A. niger } \\
\text { AZN 8240 }\end{array}$ \\
\hline Compound (1) & $\mathrm{Nt}$ & $\mathrm{Nt}$ & $\mathrm{Nt}$ & $\mathrm{Nt}$ \\
Compound (2) & 3 & 3 & 1.5 & 0.75 \\
Compound (3) & 0.07 & 0.07 & 0.07 & - \\
Compound (4) & 1.6 & 3.1 & 6.2 & 1.2 \\
Crude extract TSR & 0.16 & 2.5 & 0.63 & - \\
Crude extract PCR & 1.25 & 0.31 & 0.04 & 0.04 \\
Clotrimazole & 0.09 & 0.19 & 0.19 & 0.05 \\
\hline
\end{tabular}

$\mathrm{TSR}=$ Terminalia sericea root crude extract, $\mathrm{PCR}=$ Parinari curatellifolia root crude extract, $\mathrm{Nt}=$ not tested 


\section{DISCUSSION}

\section{Isolated compounds}

The ${ }^{1} \mathrm{H}$ and ${ }^{13} \mathrm{C}$ NMR data in Table 1 and information from the literature revealed that compound (1), was a known compound 6[(2R)-2,3-dihydroxy-3-methyl-butyl]-5,7dimethoxy-coumarin a toddalolactone ( $\mathrm{Yu}$ et al., 2017). The presence of this diterpene lactone (1), in Parinari species which belongs to the family Chrysobalanaceae is noteworthy, since this type of compounds were mostly reported in the Rutaceae family (Hisashi et al., 1991)

The ${ }^{13} \mathrm{C}-\mathrm{NMR}$ spectrum of compound (2) indicated the presence of carbonyl characteristic for a ketone at $\delta 208.3 \mathrm{ppm}$, and a carboxyl functional group at $\delta 180.6 \mathrm{ppm}$, as well as an exocyclic methylidene group at $\delta$ 147.6 (quaternary $\mathrm{C}$-atom) and at $\delta 116.7$ $(=\mathrm{CH}$, $) \mathrm{ppm}$. In the 'H-NMR, two olefinic protons were clearly visible at $\delta 5.36$ and $\delta 6.13$ ppm. From these data, compound (2) was assigned as a kaurenoid diterpene. Spectral data of this compound was confirmed to be similar with already reported data by Garo et al. (1997).

The structures of Sericic acid (3) and Sericoside (4), indicated the characteristic feature of oleanene moiety based on extensive spectroscopic analysis in the ${ }^{1} \mathrm{H}$ and ${ }^{13} \mathrm{C}$ NMR including two- and three-dimensional NMR techniques. The structures for compounds were deduced from the comparison of the observed NMR spectral features (Table 2) with those reported in the literature for these compounds (Terreaux et al., 1996; Hess and Monache, 1999) . Also, confirmation of chemical shift of Sericic acid was done by comparing ${ }^{13} \mathrm{C}$ NMR chemical of related compounds arjungenin (Aimée et al., 2017) and tomentosic acid (Mahato et al., 1990) both found in Terminalia species. Comparing carbon and proton spectral data for Compound (3) and (4) indicates that, the only difference between the two was the presence of glucoside moiety. Therefore, Compound (4) is a glycoside of compound (3) been referred to as sericoside due to observed $J$ value on the attachment of the hexose moiety of the $\beta$-glucose at $\mathrm{C}-1$ axial proton.

\section{Antifungal activity of fractions and compounds}

The results in Table 5 showed that, crude extracts and isolated compounds from Parinari curatellifolia and Terminalia sericea were active against the tested pathogenic fungi demonstrating varying antifungal activity. Crude extract from Parinari curatellifolia revealed strong antifungal activity (MIC $=0.75$ $\mathrm{mg} / \mathrm{ml}$ ) against $C$. albicans comparatively higher compared to the isolated compound 10hydroxy-13-methoxy-9- methyl-15-oxo-20norkaur-16-en-18-oic acid t-lactone (2) (MIC $=3 \mathrm{mg} / \mathrm{ml}$ ) from the same plant extract. The observed lower activity for the 10-hydroxy-13methoxy-9- methyl-15-oxo-20-norkaur-16-en18-oic acid t-lactone, Sericic acid and Sericoside compounds compared to crude extracts from the respective plants (Mbunde et al., 2019) can be explained by mechanism of interaction induced by several compounds in fraction or crude form that my enhance activity positively synergism) and negatively (antagonism) against the fungal pathogens.

Interestingly, to the best of our knowledge bioactivity of these compounds against human pathogenic microbes Candida albicans, Cryptococcus neoformans and Aspergillus niger is being reported for the first time. Antifungal activity has only been reported for 10-hydroxy-13-methoxy-9methyl-15-oxo-20-norkaur-16-en-18-oic acid t-lactone in phytopathogenic fungus Cladosporium cucumerin (Garo et al., 1997). Other biological activities for 10-hydroxy-13methoxy-9-methyl-15-oxo-20-norkaur-16-en18-oic acid t-lactone reported in malaria against Plasmodium falciparum (Uys et al., 2002). Toddalolactone (1) on the other hand was not subjected to assay because the amount isolated was very small. However, it has been reported in the literature to have antihypertension, anti-inflammatory, antifungal activities (Upadhyay, 2016), larvicidal, antifibrotic and anti-thrombotic activity (Yu et al., 2017).

Findings from our study revealed that, Sericic acid (3) from $T$. sericea had stronger antifungal activity (MIC $=0.068 \mathrm{mg} / \mathrm{ml}$ ) than 
the tested known standard drug clotrimazole $(\mathrm{MIC}=0.09 \mathrm{mg} / \mathrm{ml})$. This may be attributed by the presence of conjugated carbons, number of phenolic, hydroxyl and carboxyl groups and the number of acceptor atoms of hydrogen bonds in the compound which are known as important structural descriptors in the antimicrobial activity of terpenes (Sieniawska and Rafal, 2017). However, weak activity of Sericoside (4) contradicts this fact hence; further studies are needed to elucidate the mechanism of actions. The two compounds from Terminalia sericea has been previously reported to contain antibacterial activity against Bacillus subtilis and Pseudomonas fluorescens with equal MIC values of $5 \mu \mathrm{g} / \mathrm{ml}$ and $>40 \mu \mathrm{g} / \mathrm{ml}$ respectively (Conrad et al., 1998) while Hess et al. (1995) reported antibacterial activity of Sericic acid against Staphylococcus aureus $(\mathrm{MIC}=1.0 \mathrm{mg} / \mathrm{ml}$ ).

\section{Conclusion}

This study reports the antifungal activity of Sericic acid for the first time while toddalolactone (1) is being isolated for the first time in $P$. curatellifolia and the family Chrysobalanaceae. Sericic acid (3) had comparable activity with the standard antifungal drug clotrimazole against Candida albicans and Cryptococcus neoformans. The observed biological activities in the crude extracts and isolated compounds justify, its popular use in Southern Tanzania for the treatment of infectious diseases.

\section{COMPETING INTERESTS}

The authors declare that they have no competing interests in the publication of this work.

\section{AUTHORS' CONTRIBUTIONS}

All authors contributed to the realization of this work. They also read and approved this manuscript.

\section{ACKNOWLEDGMENTS}

Authors are grateful to the Muhimbili University of Health and Allied Sciences, Tanzania and Stockholm
University, Sweden for laboratory facilities to enable our research and financial support from the Swedish Research Council.

\section{REFERENCES}

Aimée M,Tchuenmogne T, Kammalac TN, Gohlke S, Marie R, Kouipou T, Aslan A, Kuzu M, Comakli V, Demirdag R, Ngouela SA, Tsamo E, Sewald N, Lenta BN, Boyom FF. 2017. Compounds from Terminalia mantaly L.(Combretaceae) Stem Bark Exhibit Potent Inhibition against Some Pathogenic Yeasts and Enzymes of Metabolic Significance. Medicines, 4(6): 1-12. DOI: https://doi.org/10.3390/medicines401000 6

Angaman RK, Orsot BMAB, Camara D, Abo K, Zirihi NG. 2018. Ethnobotanical study of flora plants from the Department of Abengourou, Ivory Coast and in vitro evaluation of the antifungal activity of extracts of Terminalia superba Engl. Diels on two species of mushrooms, Aspergillus niger Van Tieghem and Fusarium so. International Journal of Biological and Chemical Sciences, 12(3): 1208.

DOI: https://doi.org/10.4314/ijbcs.v12i3.11

Chhetri HP, Yogol NS, Sherchan J, Anupa KC, Mansoor S, Thapa P. 2010. Formulation and Evaluation of Antimicrobial Herbal Ointment. Kathmandu University Journal of Science, Engineering and Technology, 6(1): $102-107 . \quad$ DOI: https://doi.org/10.3126/kuset.v6i1.3317

Chukwudi U, Ayodeji F, Amos J, Olawunmi O. 2014. Antibacterial activity and phytochemical evaluation of the leaf root and stem bark extracts of parinari curatellifolia (planch. ex benth). International Journal of Advanced Chemistry, 2(2): 178. DOI: https://doi.org/10.14419/ijac.v2i2.3568

Conrad J, Vogler B, Klaiber I, Roos G, Walter U, Kraus W. 1998. Two triterpene esters from Terminalia macroptera bark. Phytochemistry, 48(4): 647-650. DOI: 
https://doi.org/10.1016/S0031-

9422(98)00154-X

Diesse JM, Kechia FA, Iwewe YS, Ngueguim AD, Nangwat C, Dzoyem JP. 2017. Urinary tract candidiasis in HIV+ patients and sensitivity patterns of recovered Candida species to antifungal drugs in Dschang District Hospital (Cameroon). International Journal of Biological and Chemical Sciences, 11(3): 1029-1038. DOI:

https://doi.org/10.4314/ijbcs.v11i3.8

Fyhrquist P, Mwasumbi L, Hæggstro“MCA, Hiltunen R, Vuorela P. 2002. Ethnobotanical and antimicrobial investigation on some species of Terminalia and Combretum (Combretaceae) growing in Tanzania. Journal of Ethnopharmacology,79:169177. DOI: https://doi.org/10.1016/S03788741(01)00375-0

Garo E, Maillard M, Hostettmann K. 1997. 42. Absolute Configuration of a Diterpene Lactone from Parinari capensis. Helvetica Chimica Acta, 80(2): 538-544. DOI: https://doi.org/https://doi.org/10.1002/hl ca. 19970800218

Gibbons S. 2004. Anti-staphylococcal plant natural products. Natural Product Reports, 21(2): 263-277. DOI: https://doi.org/10.1039/b212695h

Hess SC, Brum RL, Honda NK, Cruz AB, Moretto E, Cruz RB, Messana I, Ferrari F, Filho VC, Yunes RA. 1995. Antibacterial activity and phytochemical analysis of Vochysia divergens (Vochysiaceae). Journal of Ethnopharmacology, 47(2): 97-100.

DOI: https://doi.org/10.1016/03788741(95)01260-k

Hess SC, Monache FD. 1999. Divergioic Acid, a Triterpene from Vochysia divergens. Journal of Brazillian Chemical Society, 2(10): 104-106. DOI: https://doi.org/10.1590/S0103505331999000200005

Hisashi I, Junichi K, Munekazu I, Joju H, Tsutom I. 1991. Studies on the chemical constituents of rutaceous plants. LXVI.
The chemical constituents of Toddalia asiatica (L.) Lam. (T. aculeata Pers.). (1). Chemical constituents of the root bark. Yakugaku Zasshi: Journal of the Pharmaceutical Society of Japan, 111(7): 365-375.

DOI: https://doi.org/10.1248/yakushi1947.111. 7

Hzounda FJB, Zeuko'O, Menkem E, Tchokouaha YLR, Ngoutane MA, Kamdem MS, Ngouana V, Kenfack IF, Boyom FF. 2017. Anti-yeast potential of some Annonaceae species from Cameroonian biodiversity. International Journal of Biological and Chemical Sciences, 11(1): $15 . \quad$ DOI: https://doi.org/10.4314/ijbcs.v11i1.2

Lee IS, Shamon LA, Chai HB, Chagwedera TE, Besterman JM, Farnsworth NR, Cordell GA, Pezzuto JM, Kinghorn AD. 1996. Cell-cycle specific cytotoxicity mediated by rearranged ent-kaurene diterpenoids isolated from Parinari curatellifolia. Chemico-Biological Interactions, 99(1-3): 193-204.

Mahato SB, Nandy AK, Luger P, Weber M. 1990. Determination of Structure and Stereochemistry of Tomentosic Acid by X-Ray Crystallography, A Novel Mechanism for Transformaton of Arjungenin to Tomentosic Acid. Journal of the Chemical Society, Perkin Transactions 2, 8:1445-1450. DOI: https://doi.org/https://doi.org/10.1039/P2 9900001445

Masoko P, Picard J, Eloff JN. 2005. Antifungal activities of six South African Terminalia species (Combretaceae). Journal of Ethnopharmacology, 99(2): 301-308. DOI: https://doi.org/10.1016/j.jep.2005.01.061

Mbunde M, Innocent E, Andersson P. 2016. Ethnobotanical survey and toxicity evaluation of medicinal plants used for fungal remedy in the Southern Highlands of Tanzania. Journal of Intercultural Ethnopharmacology, 6(1): 84-96. DOI: https://doi.org/10.5455/jice.2016122210 3956 
Mbunde M, Mabiki F, Innocent E, Andersson P. 2019. Antifungal activity of single and combined extracts of medicinal plants from Southern Highlands of Tanzania. Journal of Pharmacognosy and Phytochemistry, 8(1): 181-187.

Nhukarume L, Chikwambi Z, Muchuweti M, Chipurura B. 2009. Phenolic content and antioxidant capacities of Parinari curatellifolia, Strychnos spinosa and Adansonia digitata. Journal of Food Biochemistry, 34(2010): 207-221. DOI : https://doi.org/10.1111/j.17454514.2009.00325.x

Ogunnusi T, Oso B, Dosumu O. 2010. Isolation and antibacterial activity of triterpenes from Euphorbia kamerunica Pax. International Journal of Biological and Chemical Sciences, 4(1): 158-167. DOI : https://doi.org/10.4314/ijbcs.v4i1.54241

Sieniawska E, Rafał S. 2017. Natural terpenes influence the activity of antibiotics against isolated Mycobacterium tuberculosis. Med. Princ. Pract., 26: 108112. DOI: https://doi.org/10.1159/000454680

Terreaux C, Maillard MP, Gupta MP,
Hostetrmannt K. 1996. Triterpenes and triterpene glycoside from Paradrymonia macrophylla. Phytochemistry, $\mathbf{4 2 ( 2 ) :}$ 495-499.

DOI: https://doi.org/https://doi.org/10.1016/00 31-9422(95)00945-0

Upadhyay RK. 2016. Toddalia aculeata: A comprehensive review of its Phytochemistry, pharmacology and its traditional use. Advances in Biomedicine and Pharmacy, 03(05): 280-290. DOI: https://doi.org/10.19046/abp.v03i05.05

Uys ACU, Malan SF, Van Dyk S, Van Zyl RL. 2002. Antimalarial compounds from Parinari capensis. Bioorganic and Medicinal Chemistry Letters, 12(16): 2167-2169.

DOI: https://doi.org/10.1016/S0960894X(02)00350-5

Yu B, Zhang G, Jin L, Zhang B, Yang H, Ye Z, Ma T. 2017. Inhibition of PAI-1 Activity by Toddalolactone as a Mechanism for Promoting Blood Circulation and Removing Stasis by Chinese Herb Zanthoxylum nitidum var. Frontiers in Pharmacology, 8(489): 1-11. DOI: https://doi.org/10.3389/fphar.2017.00489 